\title{
Psychometric Properties of the EFL Learning Plateau Inventory for Medical Students
}

\author{
Mehdi Mirzaei $^{* 1}$ (D), Masoud Zoghi ${ }^{1}$ (D), Haniyeh Davatgari Asl ${ }^{1}$ (ID)
}

${ }^{1}$ Department of English Language and Literature, Ahar Branch, Islamic Azad University, Ahar, Iran.

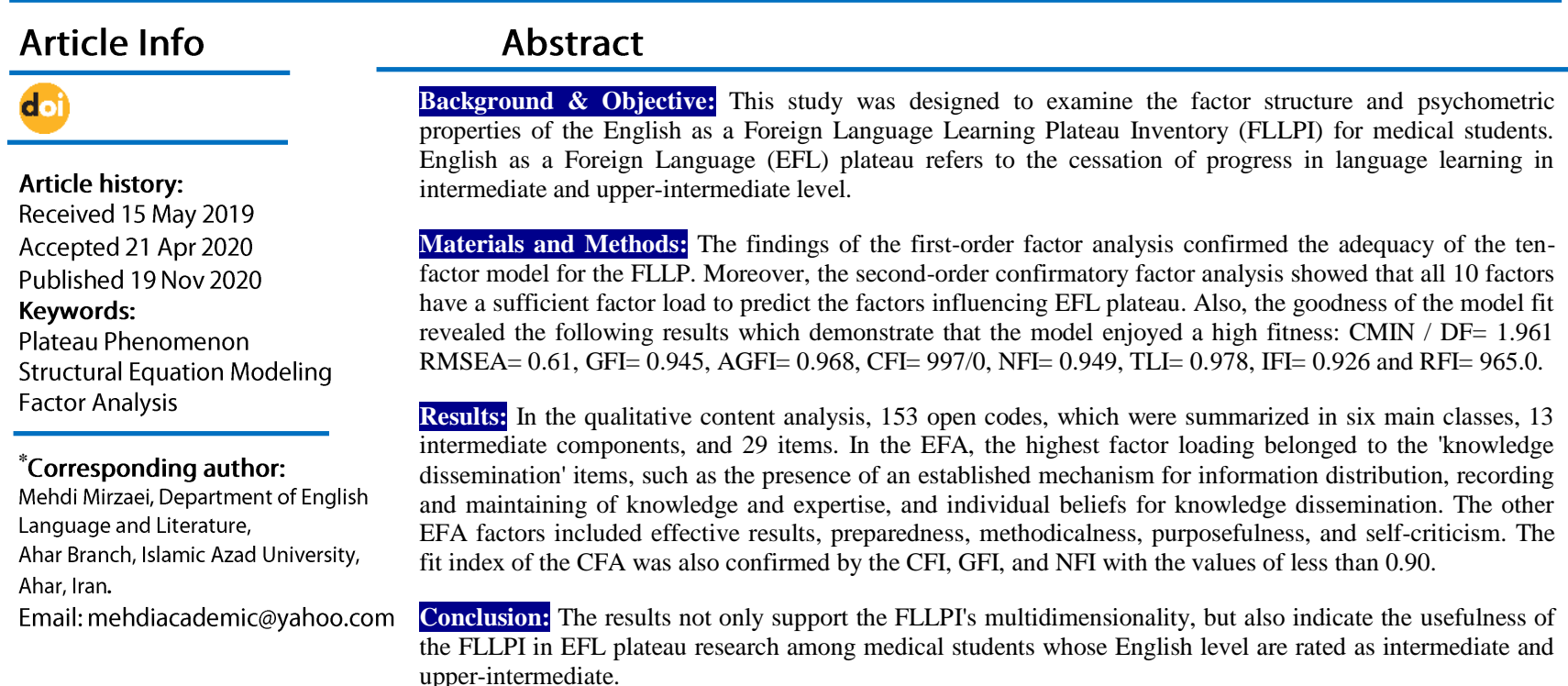
upper-intermediate.

\section{Introduction}

According to Richards (1), a large number of English as a Foreign Language (EFL) learners who move from the lower-intermediate to the upperintermediate/advanced level of language proficiency "appear to have reached a plateau in their language learning and do not perceive that they are making further progress" (1). This is known as Plateau Phenomenon which refers to the problems that EFL learners encounter when they reach intermediate and upper-intermediate levels of language proficiency and they hit a plateau in language learning and feel that their learning improvement is slowing down. Similarly, Rowntree (2) states that on the language learning curve, progress is very quick in the initial stages and then the rate of improvement slows right down to almost nothing. It is during this period of time that many EFL learners experience anxiety which impedes their further efforts in progressing in learning English (3).

According to $\mathrm{Yi}$ (3), since every input in the foreign language is new and challenging for learners at the very beginning of language learning, they are highly motivated to learn and they use the newly-learned materials to communicate in the foreign language. During this period, the learners continually absorb new linguistic items and employ them in their speech because they are highly motivated to learn and everything seems to be new and applicable to produce novel sentences. As a result, the learners' progress is apparent until a certain degree that they feel satisfied with their current state of linguistic knowledge and perceive that they can easily communicate in the target language. "It is during this stage that they hit a plateau and do 
not perceive that they are making further progress" (1. P. 1).

However, Richards (1) and Yi (3) state that the language learning plateau in foreign language learning development is not everlasting and we can conquer learning plateau using specific pedagogical procedures. In the same way, Shormani (4) considers language learning plateau as a provisional pause in learning progress of L2 learners who are moving to a more advanced level after reaching a certain degree. It seems logical to state that there is a gap between what language teaching practitioners presume their learners are gaining in the higher levels of language learning and the actual competency they show to have gained. Their gained competency is less likely to correspond with the objectives of that level especially when learners pass the intermediate level (5).

In this regard, Lewis (6) states that students in upper-intermediate level can handle communication in most situations, but they tend to 'avoid' or 'talk around' the more challenging tasks of advanced language learning. In fact, having experienced a lot of novelty in the presentation of teaching materials and linguistic items in elementary and intermediate levels, upper-intermediate learners hardly find newness in the materials or structural properties of language which causes they remain in the same point and their progress fails to mount as the time passes. There are diverse reasons to this such as they feel that they can survive in an English context with their present linguistic knowledge or the specific version of language they speak is fossilized and seems to be unchangeable.

A fact regarding language learning in intermediate and upper-intermediate level is that although learners have struggled long to learn English through years, there is a mismatch between what they have achieved and what they expect to. This mismatch should be wake-up call for intermediate upper-intermediate learners as well as teaching practitioners to come to the understanding that there is deficiency in the process of EFL teaching-learning which must be effectively dealt with and solutions be provided in order to prevent this plateau.

Reaching plateau is a stage in language learning, as we switch from intensive learning to consolidation before proceeding further. An assumption that many learners have is that an English knowledge of intermediate level is enough for everyday life because they think that they can manage to communicate. This is one reason that they lose motivation to grasp more of language. Consequently, without motivation, success in language learning is almost impossible (9).

Past research indicates that most medical students in Iran enjoy at least an intermediate knowledge of English (10); however, the plateau effect of language learning among the students of this field has not been studied. EFL plateau phenomenon is a challenge which requires a deep analysis from both qualitative and quantitative perspectives. Mirzaei, et.al (5) looked into the problem qualitatively using grounded theory. In their study, they investigated EFL plateau phenomenon from the intermediate and upperintermediate learners' perspectives through conducting semi-structured interviews and they analyzed the data using the principles of grounded theory. The product was a theory which demonstrated the relationship among the contributing factors which played a role in EFL plateau. There were three main influences; namely Instruction-Related Variables, LearnerRelated Variables, and Going through Problems which accounted for this phenomenon. In their study, Instruction-Related Variables included curriculum and syllabus, teacher action, assignments, and learning activities, LearnerRelated Variables included learners' affection, learners' cognition, learners' meta-cognition, learning strategies, and language automatization. Finally, Going through Problems incorporated the subcategory of unpleasant learning experiences.

The factors mentioned above were produced using a qualitative data analysis, i.e. Grounded Theory. However, the present study was conducted to quantitatively look into the problem 
and make use of the results of the study by Mirzaei, et.al (5) to provide statistical support for those findings. Therefore, like Zoghi's (11) study, it was considered necessary to conduct a factor analytic study on the EFL plateau phenomenon so that it could be possible to re-assess and also to firmly establish construct validity of this phenomenon. Moreover, in this research, it has been attempted to assess the factor structure of this newly-developed theory. Thus, the main purpose of this study was to extend the existing research on EFL plateau phenomenon by testing the factor structure of the phenomenon among medical students whose English level was rated as intermediate and upper-intermediate by means of confirmatory factor analysis (CFA).

\section{Materials and Methods}

1. Participants of the Study

This SEM (Structural Equation Modeling) study was conducted with a sample of 312 participants from Zanjan University of Medical Sciences, Qazvin University of Medical Sciences and Alborz University of Medical Sciences who agreed to participate in this study. A nonprobability sampling technique known as convenience sampling was used since the participants were selected because of their convenient accessibility and characteristics pertinent to the objectives of the study. The first language of the participants was Azeri and Farsi. Their proficiency level of English, which was found to be either at intermediate or higher level, was tested through conducting Oxford Placement Test (OPT).

\section{Instrument of the Study}

The first instrument was OPT to choose the participants who were at intermediate or higher level of language proficiency. As well as the placement of students in appropriate instructional levels, the OPT was designed for the measurement of students' English proficiency (12). For instance, previous research has shown that the OPT can also be used to evaluate the degree of learners' L2 proficiency (13).
Secondly, the main research instrument of the study, the FLLPI, consisted of 44 items that were rated on a 4-point Likert-type format, with 1 (strongly disagree) to 4 (strongly agree). Scores range from a low of 44 to a high of 176 , with higher scores reflecting stronger belief in the influence power of the item in FLLPI. The FLLPI has ten sections that match the three main influencing factors emerged in the qualitative data analysis (grounded theory) in Mirzaei's, et.al (5) study. The three sections are (i) Learnerrelated Variables, (ii) Instruction-related Variables, and (iii) Going through Problems. The FLLPI has previously been reported as having acceptable validity and reliability (5).

\section{Procedure}

Through the convenience sampling method, a sample of 312 participants, who were medical students of Zanjan University of Medical Sciences, Qazvin University of Medical Sciences and Alborz University of Medical Sciences, were chosen. As a result of the administration of the OPT, a sample of 210 medical students, whose English level was rated as intermediate or higher level of English language proficiency, was chosen. Within a period of 10 days, the FLLPI questionnaire was administered. Although some respondents ignored a few items, most of the questionnaires were fully completed and handed in. Finally, the data were entered into SPSS 24 for relevant analysis.

\section{Statistical Analysis}

Subjects' responses to the FLLPI were coded and entered into SPSS 24. Before testing the factor structure, a descriptive overview of the data set was provided to obtain descriptive statistics related to normality and detection of outliers. The mean, standard deviation, skewness, and kurtosis, did not specify any strong violation of the related assumptions. Therefore, the intended statistical tests were conducted.

Since FLLPI was based on a solidly validated Grounded Theory, only CFA was conducted on the inventory. Therefore, structural equation modeling (SEM) was conducted using AMOS 24. 
SEM is a confirmatory technique (14). This analysis calls for a priori hypotheses about (a) the number of factors, (b) whether the factors are correlated or not, and (c) which items load onto and reflect which factors. In addition to the above statistical procedures, the internal consistency or reliability of the FLLPI was estimated by determining the coefficient alpha.

\section{Results}

\section{KMO \& Bartlett's}

In order to analyze the quantitative data, SPSS 24 and AMOS 24 were used. The Kaiser-MeyerOlkin (KMO) measure of sampling adequacy, Bartlett's test of sphericity, and the anti-image correlation matrix were checked. The KMO analysis verified the sampling adequacy for the analysis, $\mathrm{KMO}=0.96$, in which according to Kaiser's (15) recommendations, values above 0.9 are excellent. The KMO values for individual variables were also examined on the diagonal of the anti-image correlation matrix. The value should be greater than 0.5 for all variables. For these data all values were well above 0.5 .

As shown in table 1, Bartlett's test of sphericity for these data reached statistical significance $\left(\chi^{2}=27057.9, \mathrm{~N}=210, \mathrm{p}<.001\right)$, suggesting the factorability of the correlation matrix. The gained information assured that factor analysis could be applied to the data.

Table 1: KMO and Bartlett's Test

\begin{tabular}{ccc}
\hline $\begin{array}{c}\text { Kaiser-Meyer-Olkin Measure of } \\
\text { Sampling Adequacy. }\end{array}$ & .966 \\
\hline Bartlett's Test of Sphericity & Approx. Chi-Square & 27057.966 \\
\hline & df & 946 \\
\hline & Sig. & .000 \\
\hline
\end{tabular}

\section{First Order CFA}

Table 2 illustrates the first order confirmatory factor analysis, with regard to every factor presented in FLLPI. As shown in the table, all sub-categories have a meaningful correlation with the main categories. In other words, the calculation of structural equations shows that all sub-components have a significant factor load.

Table 2: Factor loads and variance for each item

\begin{tabular}{|c|c|c|c|}
\hline $\begin{array}{c}\text { Main } \\
\text { Categories }\end{array}$ & Items & $\begin{array}{l}\text { Factor } \\
\text { Load }\end{array}$ & Variance \\
\hline \multirow{5}{*}{ Teacher Action } & Teacher should be more strict & 0.927 & 0.8593 \\
\hline & Teacher should encourage learners & 0.886 & 0.7850 \\
\hline & $\begin{array}{l}\text { English can be taught through films \& } \\
\text { songs }\end{array}$ & 0.958 & 0.9178 \\
\hline & $\begin{array}{l}\text { Teacher should make learners utilize } \\
\text { advanced vocabulary }\end{array}$ & 0.940 & 0.8836 \\
\hline & Teacher should give translation tasks & 0.959 & 0.9197 \\
\hline \multirow{5}{*}{ Assignments } & $\begin{array}{l}\text { Teacher should give appropriate } \\
\text { amount of homework }\end{array}$ & 0.899 & 0.8082 \\
\hline & Teacher should assign lectures & 0.946 & 0.8949 \\
\hline & Teacher should assign writing & 0.878 & 0.7709 \\
\hline & $\begin{array}{l}\text { Teacher should give appropriate } \\
\text { practice inside the class }\end{array}$ & 0.934 & 0.8724 \\
\hline & $\begin{array}{l}\text { Teacher should do more classroom } \\
\text { questioning }\end{array}$ & 0.954 & 0.9101 \\
\hline \multirow{3}{*}{$\begin{array}{l}\text { Curriculum and } \\
\text { Syllabus }\end{array}$} & $\begin{array}{l}\text { Reading \& Vocabulary have become } \\
\text { more difficult }\end{array}$ & 0.945 & 0.8930 \\
\hline & Some grammar is only repeated & 0.842 & 0.7090 \\
\hline & The books have become more difficult & 0.965 & 0.9312 \\
\hline
\end{tabular}




\begin{tabular}{|c|c|c|c|}
\hline & Lessons should be interesting & 0.971 & 0.9428 \\
\hline \multirow{5}{*}{$\begin{array}{l}\text { Learning } \\
\text { Activities }\end{array}$} & $\begin{array}{l}\text { Students should become independent } \\
\text { in learning }\end{array}$ & 0.967 & 0.9351 \\
\hline & $\begin{array}{l}\text { Students should know how to learn } \\
\text { (learning strategy) }\end{array}$ & 0.981 & 0.9624 \\
\hline & $\begin{array}{l}\text { Students should have active } \\
\text { participation in class }\end{array}$ & 0.969 & 0.9390 \\
\hline & Students should have learning goals & 0.859 & 0.7379 \\
\hline & Students' mistakes should decrease & 0.972 & 0.9448 \\
\hline \multirow{4}{*}{ Meta-cognition } & $\begin{array}{l}\text { Students should think why their marks } \\
\text { are decreasing }\end{array}$ & 0.970 & 0.9409 \\
\hline & Students should have plans for learning & 0.943 & 0.8892 \\
\hline & $\begin{array}{l}\text { Students should use new words in role } \\
\text { plays }\end{array}$ & 0.951 & 0.9044 \\
\hline & $\begin{array}{l}\text { Students should use new words in } \\
\text { speaking and writing }\end{array}$ & 0.961 & 0.9235 \\
\hline \multirow{4}{*}{$\begin{array}{l}\text { Learning } \\
\text { strategies }\end{array}$} & Students should use flashcards & 0.956 & 0.9139 \\
\hline & $\begin{array}{l}\text { Students should have regular review of } \\
\text { lessons }\end{array}$ & 0.891 & 0.7939 \\
\hline & $\begin{array}{l}\text { Students should talk with a native } \\
\text { speaker }\end{array}$ & 0.877 & 0.7691 \\
\hline & Students should learn about culture & 0.979 & 0.9584 \\
\hline \multirow{4}{*}{$\begin{array}{l}\text { Learners' } \\
\text { Cognition }\end{array}$} & $\begin{array}{l}\text { Students repeat the same mistakes } \\
\text { again and again }\end{array}$ & 0.981 & 0.9624 \\
\hline & $\begin{array}{l}\text { mistakes should be corrected } \\
\text { immediately }\end{array}$ & 0.954 & 0.9101 \\
\hline & $\begin{array}{l}\text { Students need to self-correct their } \\
\text { mistake }\end{array}$ & 0.926 & 0.8575 \\
\hline & $\begin{array}{l}\text { Some Students should go back to the } \\
\text { elementary levels }\end{array}$ & 0.984 & 0.9683 \\
\hline \multirow{4}{*}{$\begin{array}{l}\text { Learners' } \\
\text { Affection }\end{array}$} & $\begin{array}{l}\text { Students should have motivation for } \\
\text { learning }\end{array}$ & 0.937 & 0.8780 \\
\hline & $\begin{array}{l}\text { Students should feel the need to learn } \\
\text { English }\end{array}$ & 0.972 & 0.9448 \\
\hline & $\begin{array}{l}\text { Students should have perseverance in } \\
\text { learning }\end{array}$ & 0.896 & 0.8028 \\
\hline & $\begin{array}{l}\text { Students do not have enough time to } \\
\text { study }\end{array}$ & 0.898 & 0.8064 \\
\hline \multirow{3}{*}{$\begin{array}{l}\text { Language } \\
\text { Automatization }\end{array}$} & Students should speak fast & 0.967 & 0.9351 \\
\hline & $\begin{array}{l}\text { Students should speak without much } \\
\text { thinking }\end{array}$ & 0.927 & 0.8593 \\
\hline & $\begin{array}{l}\text { Students should remember the correct } \\
\text { words and structures quickly }\end{array}$ & 0.987 & 0.9742 \\
\hline \multirow{6}{*}{$\begin{array}{l}\text { Unpleasant } \\
\text { Learning } \\
\text { Experiences }\end{array}$} & $\begin{array}{l}\text { I cannot learn speaking and grammar } \\
\text { anymore }\end{array}$ & 0.916 & 0.8391 \\
\hline & I am moving forward very slowly & 0.958 & 0.9178 \\
\hline & My marks keep decreasing & 0.960 & 0.9216 \\
\hline & $\begin{array}{l}\text { I can get by with my present } \\
\text { knowledge of English }\end{array}$ & 0.956 & 0.9139 \\
\hline & $\begin{array}{l}\text { Teacher should give translation from } \mathrm{L} 1 \\
\text { to } \mathrm{L} 2\end{array}$ & 0.938 & 0.8798 \\
\hline & We speak slowly like elementary levels & 0.969 & 0.9390 \\
\hline
\end{tabular}

2.1 Evaluation of Model Fit of the First Order CFA

In order to make sure of a good fit between the model and the data, several statistical tests are required by CFA. Likewise, in the present research, it was necessary to evaluate the overall fit of the model by the data. Hooper, Coughlan, and Mullen (16, p. 56) citing Crowley and Fan (17) assert that there are no hard and fast rules for assessment of model fit and we need to use various fit measures as "different indices reflect a different aspect of model fit." Among the various model fit statistics which calculate the goodnessof-fit indices, the following indices were calculated in this research: the chi-squared test $\left(x^{2}\right)$ and its ratio with degrees of freedom ( $x^{2} /$ df), goodness-of-fit index (GFI), adjusted goodness-of-fit index (AGFI), normed fit index (NFI), comparative fit index (CFI), and root mean square error of approximation (RMSEA), as 
recommended by Boomsma (18), Kline (19), and Tabachnick and Fidell (20).

Regarding the mentioned metrics, some of them have different acceptable thresholds. For this study, a good model fit was defined by chi-p $\geq$ 0.05 , GFI $\geq 0.90$, CFI close to 1.0 , AGFI $\geq 0.90$, RMSEA $\leq 0.08$, and NFI $\geq 0.90$ (15- 17).

Table 3: Goodness-of-Fit Indices for the First Order CFA

\begin{tabular}{|c|c|c|c|c|c|c|c|c|c|}
\hline \multirow[t]{2}{*}{ Items } & \multicolumn{9}{|c|}{ Fitness Indices } \\
\hline & $\mathrm{RFI}$ & IFI & TLI & $\mathrm{NFI}$ & CFI & AGFI & GFI & RMSEA & CMIN/DF \\
\hline Teacher Action & 0.953 & 0.924 & 0.933 & 0.925 & 0.902 & 0.955 & 0.920 & 0.60 & 1.725 \\
\hline Assignments & 0.919 & 0.975 & 0.981 & 0.931 & 0.964 & 0.928 & 0.982 & 0.53 & 1.123 \\
\hline $\begin{array}{c}\text { Curriculum and } \\
\text { Syllabus }\end{array}$ & 0.929 & 0.944 & 0.9650 .9 & 0.913 & 0.945 & 0.924 & 0.934 & 0.56 & 2.342 \\
\hline $\begin{array}{l}\text { Learning } \\
\text { Activities }\end{array}$ & 0.947 & 0.958 & 0.975 & 0.917 & 0.972 & 0.970 & 0.951 & 0.59 & 2.678 \\
\hline Meta-cognition & 0.983 & 0.931 & 0.908 & 0.926 & 0.946 & 0.959 & 0.915 & 0.52 & 1.526 \\
\hline $\begin{array}{l}\text { Learning } \\
\text { strategies }\end{array}$ & 0.937 & 0.916 & 0.928 & 0.919 & 0.936 & 0.985 & 0.977 & 0.76 & 1.448 \\
\hline $\begin{array}{l}\text { Learners' } \\
\text { Cognition }\end{array}$ & 0.901 & 0.962 & 0.957 & 0.987 & 0.958 & 0.928 & 0.914 & 0.51 & 1.661 \\
\hline $\begin{array}{l}\text { Learners' } \\
\text { Affection }\end{array}$ & 0.972 & 0.954 & 0.969 & 0.991 & 0.962 & 0.948 & 0.911 & 0.54 & 1.736 \\
\hline $\begin{array}{c}\text { Language } \\
\text { Automatization }\end{array}$ & 0.958 & 0.989 & 0.914 & 0.953 & 0.953 & 0.935 & 0.921 & 0.58 & 2.212 \\
\hline $\begin{array}{l}\text { Unpleasant } \\
\text { Learning } \\
\text { Experiences }\end{array}$ & 0.988 & 0.937 & 0.983 & 0.935 & 0.984 & 0.963 & 0.965 & 0.55 & 1.816 \\
\hline
\end{tabular}

The ratio of chi-square to degrees of freedom is a good index for assessing a good model. For the normed $x^{2}$ / df ratio, values less than 3 represent a reasonable fit (Hair et al., 2006). It is evident in Table 3 that the $\mathrm{X}^{2} / \mathrm{df}$ ratio is less than $3\left(\mathrm{x}^{2} / \mathrm{df}\right.$ $=1.72)$ in this data sample, meaning that the tenfactor model provided acceptable fit for the data. Although the normed chi-square ratio is used as a popular way of evaluating model fit, other fit indexes have been offered to supplement and test the goodness of the model fit.

In viewing Table 3, the values of GFI, AGFI, NFI, and CFI indicated a goodness-of-fit between the ten-factor model and the sample data (GFI $=0.92$; AGFI $=0.95 ; \mathrm{NFI}=0.92$; and CFI $=0.90$ ). Much in the same way, the value obtained for the RMSEA indicated a well-fitting model (RMSEA = 0.060). As it is clear, almost all the GFIs used in this study provided statistical support for the tenfactor model. Therefore, according to Table 3, it is demonstrated that the data of the present study has a good fit with the factor structure of the components.

\section{Second Order CFA}

In the second-order factor analysis, SEM, latent factors (components), which are measured using observed variables (sub-components), are themselves influenced by an underlying variable, i.e. hidden variable, but at a higher level (21). In this research, the second-order factor analysis consists of 10 factors. Based on this, Xi1 (Designed Pattern) is considered as a latent variable, and Eta1 to Eta10 are the observed variables which are affected by the underlying latent variable $\mathrm{X}$. Considering the fact that FLLPI includes 10 factors which function as the index of this structure, second order factor analysis has been investigated regarding the validity of the factor structure of the model. The results of the second-order CFA are presented in Table 4 and its conceptual diagram is presented in Fig. 1. 
Table 4. Factor Loads

\begin{tabular}{cccc}
\hline & Factor Load & Factor & Symbol \\
\hline 1 & 1.004 & Teacher Action & Eta1 \\
\hline 2 & 0.999 & Assignments & Eta2 \\
\hline 3 & 0.975 & Curriculum and Syllabus & Eta3 \\
\hline 4 & 0.993 & Learning Activities & Eta4 \\
\hline 5 & 0.998 & Meta-Cognition & Eta5 \\
\hline 6 & 0.999 & Learning strategies & Eta6 \\
\hline 7 & 0.996 & Learners' Cognition & Eta7 \\
\hline 8 & 0.971 & Learners' Affection & Eta8 \\
\hline 10 & 0.971 & Language Automatization & Eta9 \\
\hline
\end{tabular}

3.1 Evaluation of Model Fit of the SecondOrder CFA

Regarding AMOS output in Table 5, the value of CMIN/DF is 1.96, and RMSEA is 0.61. In addition, $\mathrm{GFI}=0.94, \mathrm{AGFI}=0.96, \mathrm{NFI}=0.94$, $\mathrm{TLI}=0.97$, IFI $=0.92$, RFI $=0.96$, and $\mathrm{CFI}=0.99$. They all indicate a good fit since they all are above 0.90 .

Table 5. Fitness Indices of the Second Order CFA

\begin{tabular}{cc}
\hline Index & Estimate \\
\hline (CMIN/DF) & 1.961 \\
\hline (RMSEA) & 0.61 \\
\hline$(\mathrm{GFI})$ & 0.945 \\
\hline$(\mathrm{AGFI})$ & 0.968 \\
\hline$(\mathrm{CFI})$ & 0.997 \\
\hline$(\mathrm{NFI})$ & 0.949 \\
\hline$(\mathrm{TLI})$ & 0.978 \\
\hline$(\mathrm{IFI})$ & 0.926 \\
\hline$(\mathrm{RFI})$ & 0.965
\end{tabular}




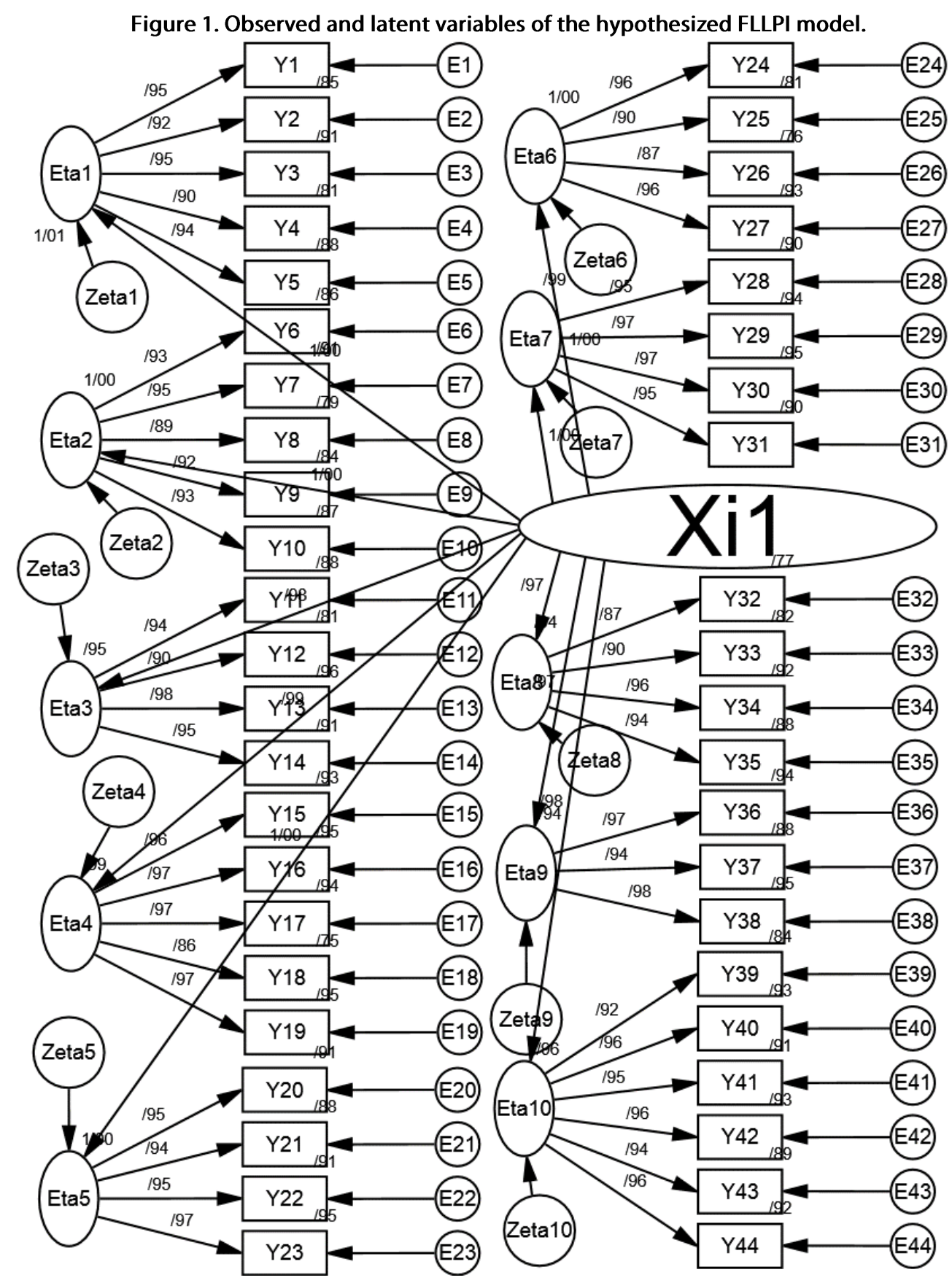

\section{Discussion}

In the current study, attempts were made to polish up the pre-existing EFL plateau inventory (FLLPI). Findings of the study provided further support for the grounded theory developed by Mirzaei, et.al (5) on EFL plateau phenomenon. The important point regarding this study is that it demonstrated that what was qualitatively obtained in the grounded theory study was quantitatively confirmed through statistical analyses, i.e. factor analysis.

A Structural Equation Modeling along with first and second order CFA was used to determine the underlying structure of the data. Similar to previous grounded theory study (5), it was found that EFL plateau phenomenon is multidimensional and three main influences account for EFL learners' not making rapid progress after reaching upper-intermediate level, 
namely, Instruction-Related Variables, LearnerRelated Variables, and Going through Problems.

As stated in the categories, the first category was referred to as Teacher Action. Among factors related to this category lie using alternative mediums of teaching such as songs, movies, and other appealing tasks such as Mobile Social Network Sites as studied by Ketabi and Kavoshian (22) which can help learners go past the plateau. Another category dealt with metacognition. The present study is in line with the idea of many researchers who have focused on the role of metacognitive awareness in students' learning outcome and have found that learners' metacognition can directly affect the process and the outcome of their learning (Eilam and Aharon (23); Mokhtari and Reichard (24). The findings of the present study can explain that when intermediate and upper-intermediate learners monitor their learning, they will notice a stage where the plateau occurs. This awareness will certainly help them devise procedures to get out of this state. Finally, this study supports previous studies (Chamot (25); Oxford and Nyikos (26); Zhang (27) which highlight the significance of learning strategies in language learning by demonstrating that when learners hit the EFL plateau, they can overcome it by devising appropriate learning strategies.

Findings of the study support that the current 44-item EFLRAI is a potentially valid and reliable measure and can be used for medical students of intermediate and upper-intermediate English knowledge. The FLLPI can be useful for educational institutions, teaching practitioners, and materials developers, and instructors. The results of the present study can be introduced to the mentioned figures in order to become aware of the potential factors which result in EFL plateau. While language teaching practitioners learn about this phenomenon, they can take effective steps to help learners tackle language learning plateau and make efforts to go past this plateau. The FLLPI can, in fact, help instructors have a multidimensional evaluation of language learning plateau, which is crucial when attempting to overcome this challenge.
The present study supports the views of Richards (1); Xu (28); and Yi (3) regarding plateau phenomenon in that when language learners reach upper-intermediate level, they experience a period of immovability in their learning progress.

\section{Conclusion}

This research demonstrated that there are inter-related factors which can give rise to language learning plateau phenomenon. The results of this study provided statistical support for the utility of the FLLPI as a psychometrically valid and reliable instrument for measuring EFL plateau among intermediate and upperintermediate language learners. The results of this study not only support the FLLPI's multidimensionality, but also indicate the usefulness of the FLLPI in EFL plateau research among medical students. With the introduction of the FLLPI, it is hoped that the present study can help add to our growing body of knowledge that we have about EFL plateau phenomenon.

\section{Limitations of the Study}

The present study suffered from a few limitations. Firstly, the subjects of the present researcher were limited to the students of medical science; however, the viewpoints of the subjects from other disciplines might have resulted in different findings. Secondly, as many other questionnaire studies, some of the questionnaires were not handed in to the researcher. Finally, lack of sufficient literature and research studies in the field of EFL plateau effect was another limitation.

\section{Recommendations for Further Research}

Results obtained from the FLLPI can help researchers conduct more studies in the field of language learning plateau. Similar research can be done to explore the ideas of instructors as how to overcome EFL plateau. Moreover, since the theoretical framework of the FLLPI was based on the grounded theory developed by Mirzaei, et.al (5), no Exploratory Factor Analysis was 
conducted in the present study. Therefore, an EFA can be conducted to explore the factors underlying FLLPI.

\section{Acknowledgments}

We are delighted to express our gratitude to all who helped us to conduct this research such as Dr. Mojtabazadeh. It should be mentioned that the present article is derived from a Ph.D. dissertation by Mehdi Mirzaei in Islamic Azad University, Ahar Branch, Iran.

Conflicts of Interest: The authors declare that there are no conflicts of interest.

\section{References}

1. Richards J. Moving beyond the plateau: from intermediate to advanced levels in language learning. New York: Cambridge University Press; 2008, 2-30.

2. Rowntree D. A dictionary of education. London: Harper and Row; 1981, 210-219.

3. Yi F. Plateau of EFL learning: A Psycholinguistic and Pedagogical Study, 2007. Retrieved from: http://citeseerx.ist.psu.edu/messages/downloadsex ceeded.html

4. Shormani M. Fossilization and plateau effect in second language acquisition. Lang India, 2013; 13(2):763-784.

5. Mirzaei $M$, Zoghi $M$, Davatgari $H$. Understanding the language learning plateau: a grounded-theory study. Teach Engl Lang. 2017; 11(2):195-222.

6. Lewis $M$. The lexical approach. Hove: Language Teaching Publications; 1993, 45-60.

7. Selinker L. Interlanguage. Ira Lang Teach. 1972; 10(4):209-232.

8. Entwistle N. Styles of learning and teaching. London: John Wiley and Sons; 1983, 142-150.

9. Williams-van C. Learning Tetun as a 'Malae'. 3rd Timor-Leste Conference, Dili, 2011.
10. Sadeghi B, Kashanian M, Maleki A, Haghdoost A. English language proficiency as a predictor of academic achievement among medical students in Iran. Theor Pract Lang St. 2013; 3(12):2315-2321.

11. Zoghi M, Alivandivafa M. EFL reading anxiety inventory (EFLRAI): factorial validity and reliability. J Psychoeduc Asses. 2014; 32(4):318-329.

12. Allen D. Oxford placement test 2 (New edition). Oxford . Oxford University Press; 1992.

13. Wistner B, Hideki S, Mariko A. An analysis of the oxford placement test and the Michigan English placement test as 12 proficiency tests. J Taka. 2008; 125(50):134-138.

14. Tabachnick B, Fidell L. Using multivariable statistics (5th ed.). Boston, MA: Allyn \& Bacon; 2007, 56-65.

15. Kaiser H. An index of factorial simplicity. Psychometrika. 1974; 39(2):31-36.

16. Hooper D, Coughlan J, Mullen M. Structural equation modeling: guidelines for determining model Fit. Electr J Bus Re Meth. 2008; 6(2):53-60.

17. Crowley S, Fan X. Structural equation modeling. In: J. Shinka, R. L Greene, Editors. Iss Meth Pers As. Hillsdale, NJ: Lawrence Erlbaum;1997, 285-308

18. Boomsma A. Reporting analyses of covariance structures. Struct Equ Modeling. 2000; 7(3):461483.

19. Kline R. B. Principles and practice of structural equation modeling (3rd ed.). New York, NY: Guilford Press; 2010, 124-130.

20. Tabachnick B, Fidell L. Using multivariable statistics (5th ed.). Boston, MA: Allyn \& Bacon. 2007.

21. Arbuckle J. Amos 23.0 user's guide. Chicago: IBM SPSS; 2014.

22. Ketabi S, Kavoshian S. Innovative technology in English language teaching: the utility of mobile social network sites to improve teacher education. Teach Engl Lang. 2017; 11(1):39-67.

23. Eilam B, Aharon I. Students' planning in the process of self-regulated learning. Contemp Educ Psychol. 2003; 28(3):304-334. 
24. Mokhtari K, Reichard C. Assessing Students' metacognitive awareness of reading strategies. J Educ Psychol. 2002; 94(2): 249.

25. Chamot A. U. Language learning strategy instruction: current issues and research. Annu Rev Appl Lingui. 2005: 25, 112-130.

26. Oxford R, Nyikos M. variables affecting choice of language learning strategies by university students. Mod Lang J. 1989; 73(3):291-300.
27. Zhang L. Constructivist pedagogy in strategic reading instruction: exploring pathways to learner development in the English as a second language (ESL) classroom. Instr Sci. 2008; 36(2):89-116.

28. Xu Q. Moving beyond the intermediate efl learning plateau. Asian Soc Sci. 2009; 5(2):65-68.

Appendix-The Questionnaire

\begin{tabular}{|c|c|c|c|c|c|}
\hline 1 & Teachers should be more strict & $\begin{array}{l}\text { Strongly } \\
\text { Disagree }\end{array}$ & Disagree & Agree & $\begin{array}{l}\text { Strongly } \\
\text { Disagree }\end{array}$ \\
\hline 2 & Teachers should encourage learners to learn & & & & \\
\hline 3 & $\begin{array}{l}\text { In Upper-intermediate level, English can be } \\
\text { taught through films \& songs }\end{array}$ & & & & \\
\hline 5 & $\begin{array}{l}\text { In Upper-intermediate level, the teacher should } \\
\text { make learners utilize advanced vocabulary }\end{array}$ & & & & \\
\hline 6 & Teachers should give translation tasks & & & & \\
\hline 7 & $\begin{array}{l}\text { In Upper-intermediate level, Teachers should } \\
\text { give appropriate amount of homework }\end{array}$ & & & & \\
\hline 8 & Teachers should assign lectures & & & & \\
\hline 9 & $\begin{array}{l}\text { In Upper-intermediate level, teachers should } \\
\text { assign writing tasks }\end{array}$ & & & & \\
\hline 10 & $\begin{array}{l}\text { Teachers should give appropriate practice } \\
\text { inside the class }\end{array}$ & & & & \\
\hline 11 & $\begin{array}{l}\text { Teachers should do more classroom } \\
\text { questioning }\end{array}$ & & & & \\
\hline 12 & $\begin{array}{l}\text { In Upper-intermediate level, reading \& } \\
\text { vocabulary have become more difficult }\end{array}$ & & & & \\
\hline 13 & $\begin{array}{l}\text { In Upper-intermediate level, some grammar is } \\
\text { only repeated }\end{array}$ & & & & \\
\hline 14 & $\begin{array}{l}\text { In Upper-intermediate level, the books have } \\
\text { become more difficult }\end{array}$ & & & & \\
\hline 15 & $\begin{array}{l}\text { In Upper-intermediate level, lessons should be } \\
\text { more interesting }\end{array}$ & & & & \\
\hline 16 & $\begin{array}{l}\text { In Upper-intermediate level, students should } \\
\text { become more independent in learning }\end{array}$ & & & & \\
\hline 17 & $\begin{array}{l}\text { In Upper-intermediate level, students should } \\
\text { know how to learn (learning strategy) }\end{array}$ & & & & \\
\hline 18 & $\begin{array}{l}\text { students should have active participation in } \\
\text { class }\end{array}$ & & & & \\
\hline 19 & Students should have learning goals & & & & \\
\hline 20 & Students' mistakes should decrease & & & & \\
\hline
\end{tabular}




\begin{tabular}{|c|c|}
\hline 21 & $\begin{array}{l}\text { Students should think why their marks are } \\
\text { decreasing }\end{array}$ \\
\hline 22 & Students should have plans for learning \\
\hline 23 & Students should use new words in role plays \\
\hline 24 & $\begin{array}{l}\text { Students should use new words in speaking and } \\
\text { writing }\end{array}$ \\
\hline 25 & Students should use flashcards \\
\hline 26 & Students should have regular review of lessons \\
\hline 27 & Students should talk with a native speaker \\
\hline 28 & Students should learn about culture \\
\hline 29 & $\begin{array}{l}\text { Students repeat the same mistakes again and } \\
\text { again }\end{array}$ \\
\hline 30 & mistakes should be corrected immediately \\
\hline 31 & Students need to self-correct their mistake \\
\hline 32 & $\begin{array}{l}\text { Some Students should go back to the } \\
\text { elementary levels }\end{array}$ \\
\hline 33 & Students should have motivation for learning \\
\hline 34 & Students should feel the need to learn English \\
\hline 35 & Students should have perseverance in learning \\
\hline 36 & Students do not have enough time to study \\
\hline 37 & Students should speak fast \\
\hline 38 & Students should speak without much thinking \\
\hline 39 & $\begin{array}{l}\text { Students should remember the correct words } \\
\text { and structures quickly }\end{array}$ \\
\hline 40 & $\begin{array}{l}\text { In Upper-intermediate level, I cannot learn } \\
\text { speaking and grammar anymore }\end{array}$ \\
\hline 41 & $\begin{array}{l}\text { In Upper-intermediate level, I am moving } \\
\text { forward very slowly }\end{array}$ \\
\hline 42 & $\begin{array}{l}\text { In Upper-intermediate level, my marks keep } \\
\text { decreasing }\end{array}$ \\
\hline 43 & $\begin{array}{l}\text { In Upper-intermediate level, I can get by with } \\
\text { my present knowledge of English }\end{array}$ \\
\hline 44 & $\begin{array}{l}\text { In Upper-intermediate level, teachers should } \\
\text { give translation from L1 to L2 }\end{array}$ \\
\hline 45 & $\begin{array}{l}\text { In Upper-intermediate level, we speak slowly } \\
\text { like elementary levels }\end{array}$ \\
\hline
\end{tabular}


Mirzaei M, Zoghi M, Davatgari Asl H. Psychometric Properties of the EFL Learning Plateau Inventory for Medical Students. J Med Educ Dev. 2020; 13 (38) :21-34 